J. Clin. Chem. Clin. Biochem.

Vol. 24, 1986, pp. $741-746$

(C) 1986 Walter de Gruyter \& Co.

Berlin - New York

\title{
Comparison of Monoclonal and Polyclonal Enzyme Immuno Assays for Carcinoembryonic Antigen
}

\section{By H. Fleuren}

Clinical Chemistry Laboratory, Hospitals of Noord-West Overijssel, Emmeloord and Kampen, The Netherlands and

\author{
R. van Oers \\ Clinical Chemistry Laboratory, Juliana Hospital, Apeldoorn, The Netherlands
}

(Received September 3, 1985/Juni 2, 1986)

Summary: A new commercially available CEA immunoassay, using monoclonal antibody, was evaluated for the purpose of routine clinical use.

The between-day coefficient of variation was $5.2 \%$ at the $6.6 \mu \mathrm{g} / 1$ level and $4.1 \%$ at the $14.2 \mu \mathrm{g} / 1$ level.

The results of analysis of sera from 260 patients were compared with the data from an established method with polyclonal antiserum. A good correlation between the two methods was found.

When the patients were classified according to groups with known types of carcinomas no systematic differences between the monoclonal and polyclonal modes of assay were apparent.

Relatively large differences in serum CEA levels did occur in individual patients necessitating a transition period in changing from one method to the other.

Vergleich von Enzymimmunoassays mit monoklonalen und polyklonalen Antikörpern für carcinoembryonales Antigen

Zusammenfassung: Ein neuer kommerziell erhältlicher Immunoassay for carcinoembryonales Antigen, der einen monoklonalen Antikörper verwendet, wurde hinsichtlich seines Einsatzes in der klinischen Routine geprüft.

Die Impräz̈ision von Tag zuu Tag betrug bei $6,6 \mu \mathrm{g} / 1$ 5,2\% und bei $14,2 \mu \mathrm{g} / \mathrm{l}$ 4,1\%. Die Ergebnisse der Untersuchung vọn Seren von 260 Patienten würden mit den Werten verglichen, die mit der gebräuchlichen Methode mit polyklonalen Antikörpern erhalten wurden. Zwischen beiden Methoden bestand eine gute Korrelation.

Nach Klassifizierung der Patienten in Gruppen mit bekannten Typen von Carcinomen wurden keine systematischen Differenzen zwischen den beiden Bestimmungsarten gefunden.

Relativ große Unterschiede in den Konzentrationen von carcinoembryonalem Antigen traten bei einzelnen Patienten auf, was eine Übergangsperiode beim Wechsel von der einen Methode zur anderen erfordert. 


\section{Introduction}

The measurement of carcinoembryonic antigen (CEA) in serum has become an important routine parameter in the postoperative management of certain malignant diseases especially of mammary cancer and of carcinomas of the digestive tract $(1,2,3)$.

In previous years CEA was measured in the authors' laboratory with an enzyme-immunoassay (EIA) from Abbott Diagnostics (Abbott, Amstelveen, The Netherlands) using a polyclonal guinea pig antibody (4, 5).

A disruption of the supply of this reagent to our country prompted us to consider an alternative mode of assay. Roche Diagnostics (Hoffmann-La Roche, Mijdrecht, The Netherlands) in 1983 introduced a solid phase EIA according to the sandwich principle. The method uses monoclonal mouse antibody against CEA coated on polystyrene beads. The second antibody is a goat anti-CEA conjugated to peroxidase. $o$-Phenylenediamine serves as the chromogenic substrate, the resulting colour being spectrophotometrically measured at $492 \mathrm{~nm}$. Because of the limited published literature on this method (6), we investigated the use of this assay for routine clinical application.

\section{Materials and Methods}

\section{Patient samples}

Blood was taken by punction from an antecubital vein into evacuated blood collecting tubes. The sera were frozen at $-20^{\circ} \mathrm{C}$ until assay. The samples originated from two hundred and sixty (260) unselected patients for whom a CEA determination had been requested by their physicians.

On one or more occasions, 325 blood samples were collected from the total group.

The patient group consisted of $64 \%$ males and $36 \%$ of females.

The age range of the males was $44-89$ years, with an arithmetic mean of 66.1 and a median value of 68.5 years. The age range of the females was 24-88 years, with an arithmetic mean of 65.8 and a median value of 66.7 years. A clinical diagnosis was available in 170 cases.

Clinically and histologically proven malignant disease was present in 112 patients (tab. 1).

The remainder showed various pathologies (diverticulitis $(n=10)$, diverticulosis $(n=5)$, polyposis coli $(n=3)$, ulcus ventriculi $(n=2)$ or no clearly abnormal findings $(n=38)$ ).

\section{CEA assay}

The patient samples were assayed in duplicate by both the polyclonal EIA from Abbott and the new monoclonal EIA from Roche. The detailed instructions of the manufacturers were followed (tab. 2). Briefly, both methods consist of a heatinactivation step of the sample followed by the immunological reactions.
Tab. 1. Distribution of carcinomas in the present study.

\begin{tabular}{lc}
\hline Type & Number of subjects \\
\hline Lung & 25 \\
Colon & 30 \\
Rectum & 31 \\
Sigmoidal & 6 \\
Stomach & 6 \\
Pancreas & 3 \\
Mamma & 11 \\
\hline
\end{tabular}

Tab. 2. Outline of steps in the assays of CEA.

\begin{tabular}{lll}
\hline & Abbott & Roche \\
\hline Sample preparation & $70^{\circ} \mathrm{C}, 15 \mathrm{~min}, \mathrm{pH} 5$ & $56^{\circ} \mathrm{C}, 30 \mathrm{~min}$ \\
Sample addition & $200 \mu \mathrm{l}$ & $50 \mu \mathrm{l}$ \\
Antibody addition & coated bead & coated bead \\
Incubation & $45^{\circ} \mathrm{C}, 2 \mathrm{~h}$ & no \\
Wash & two times & no \\
$\begin{array}{l}\text { Enzyme-labeled 2nd } \\
\text { antibody addition }\end{array}$ & $200 \mu \mathrm{l}$ & $200 \mu \mathrm{l}$ \\
$\begin{array}{l}\text { Incubation } \\
\text { Wash }\end{array}$ & $45^{\circ} \mathrm{C}, 2 \mathrm{~h}$ & $37^{\circ} \mathrm{C}, 16-24 \mathrm{~h}^{*}$ ) \\
$\begin{array}{l}\text { Addition of } \\
\text { chromogenic }\end{array}$ & $300 \mu \mathrm{l}$ & three times \\
$\begin{array}{c}\text { substrate } \\
\text { Incubation }\end{array}$ & $500 \mu \mathrm{l}$ \\
$\begin{array}{l}\text { Addition of } 1 \mathrm{~mol} / 1 \\
\text { hydrochloric acid }\end{array}$ & $18-25^{\circ} \mathrm{C}, 30 \mathrm{~min}$ & $18-26^{\circ} \mathrm{C}, 30 \mathrm{~min}$ \\
\hline
\end{tabular}

*) A $4 \mathrm{~b}$ protocol also became available upon completion of the manuscript, and a $1 \mathrm{~h}$ protocol became available in the USA.

In the Abbott assay use was made of two incubation periods of two hours, in the Roche assay a single overnight incubation step was used. After this incubation the bound peroxidase label converts the substrate 0 -phenylenediamine into 2,2-diaminoazobenzene, which is spectrophotometrically measured at $492 \mathrm{~nm}$

A calibration graph is prepared by use of the CEA standards included in each kit.

In order to study the precision of the Roche method three batches of the Roche reagent with different lot numbers ( $a, b$, c) were used. Pools of fresh patient sera were prepared, divided into portions and kept frozen until the assay date at $-20^{\circ} \mathrm{C}$.

Within-day precision was obtained by analysis of ten replicate samples of each pool. The concentrations of CEA used are indicated in the ,results section".

Between-day precision was calculated from the results obtained with two pool sera.

These were assayed in duplicate on ten different days spread over a two-month period together with the control material supplied with the kit.

The linearity of the Roche assay was studied by analysing dilutions of 3 human sera with CEA concentrations below 20 $\mu \mathrm{g} / \mathrm{l}$. The samples were diluted with the zero standard of the kit to $10,20,40,60,80 \%$ of the original concentrations. This consists of a $0.2 \mathrm{mmol} / \mathrm{l}$ acetate buffer at $\mathrm{pH} 5.0$. 
In addition, ten sera of high CEA concentration (approximate range $200-1500 \mu \mathrm{g} / \mathrm{l}$ ) were diluted with the zero standard. For each sample different degrees of dilution were applied, resulting in concentrations within the measuring range.

For instance, suppose one of the sera contained a CEA concentration of $360 \mu \mathrm{g} / \mathrm{l}$. After being diluted twenty, forty and eighty times the sample should ideally show concentrations of 18, 9 and $4.5 \mu \mathrm{g} / 1$ respectively. In order to obtain the relative recoveries the concentration calculated by using the largest dilution was arbitrarily taken as one hundred percent for each sample.

Four of these sera were also diluted with human zero serum in the same way. This zero serum consisted of a pool of samples in which previous assays had shown CEA concentrations less than $0.5 \mu \mathrm{g} / \mathrm{l}$.

\section{Results}

\section{Precision of the Roche assay}

The coefficient of variation (CV) for measurement of CEA in the individual tubes within the series ranged between 2.3 and $10 \%$. By taking the square root of these figures the CV for a CEA assay performed in duplicate was obtained. It ranged from 1.5 to $3.2 \%$ within the day (tab. 3).

Table 4 shows the reproducibility of the assay using duplicate samples over a two-month period. CVs of approximately $5 \%$ were obtained. It was observed that calculation over a longer period gave rise to larger values for the CV. For example, over a four-

Tab. 3. Within-series precision of Roche CEA method.

\begin{tabular}{|c|c|c|c|}
\hline \multirow[t]{2}{*}{ Lot } & \multirow{2}{*}{$\begin{array}{l}\text { Mean } \\
\text { concentration } \\
(\mu \mathrm{g} / \mathrm{l})\end{array}$} & \multicolumn{2}{|c|}{ Variation coefficient $\left.(\%)^{*}\right)$} \\
\hline & & in single tube & $\begin{array}{l}\text { determination } \\
\text { in duplicate }\end{array}$ \\
\hline a & $\begin{array}{r}4.9 \\
17.6\end{array}$ & $\begin{array}{l}5.5 \\
4.9\end{array}$ & $\begin{array}{l}2.3 \\
2.2\end{array}$ \\
\hline b & $\begin{array}{l}2.8 \\
3.7 \\
6.8 \\
7.3\end{array}$ & $\begin{array}{r}10.0 \\
3.1 \\
10.0 \\
9.7\end{array}$ & $\begin{array}{l}3.2 \\
1.8 \\
3.2 \\
3.1\end{array}$ \\
\hline c & $\begin{array}{r}2.9 \\
15.6 \\
61\end{array}$ & $\begin{array}{l}2.3 \\
4.2 \\
3.5\end{array}$ & $\begin{array}{l}1.5 \\
2.0 \\
1.9\end{array}$ \\
\hline
\end{tabular}

*) Number of replicates is ten for all experiments.

Tab. 4. Between-day precision of Roche CEA method.

\begin{tabular}{lcl}
\hline & $\begin{array}{l}\text { Mean } \\
\text { concentration } \\
(\mu \mathrm{g} / \mathrm{l})\end{array}$ & $\begin{array}{l}\text { Variation } \\
\text { coefficient*) } \\
(\%)\end{array}$ \\
\hline Serum low & 6.6 & 5.2 \\
Serum high & 14.2 & 4.1 \\
Kit control $(7.6 \mu \mathrm{g} / \mathrm{l})$ & 7.4 & 4.7 \\
\hline
\end{tabular}

*) Ten days spread over a two-month period. month period, CVs of $11 \%$ and $12 \%$ respectively can be calculated for the two pool sera of table 4. The larger CVs at long term were due to an apparent decrease of immunoreactive CEA concentration during storage of our samples at $-20^{\circ} \mathrm{C}$. This downward drift was about $15 \%$ from the original values over a four to six-month period. It was visible with all our frozen control sera, both with the Roche and Abbott assays.

\section{Linearity of Roche assay}

The actual concentrations found for the sera diluted with the zero standard solution of the kit were plotted against the values theoretically expected (not shown). Linear graphs were obtained within the measuring range of the assay $(0-20 \mu \mathrm{g} / \mathrm{l})$.

Furthermore the deviations of the individual points from the graphs were within the precision limits of the assay indicated by table 3 .

Sera with high CEA concentrations were diluted to different degrees ranging from 10,20 and 40 times to 100,200 and 400 times, in order to achieve values within the measuring range.

The various dilutions with the zero standard of the kit resulted in approximately identical concentrations after correction for the dilution factors applied. The relative recoveries of the diluted samples ranged from 93 to $120 \%$. A mean recovery of $98 \% \pm 9$ (1 SD) was obtained.

The dilutions with human pool serum yielded lower values for the apparent CEA concentrations in comparison with the same samples diluted with the zero standard of the kit. The relative recoveries ranged from 83 to $92 \%$. The mean recovery was $89 \pm 4 \%$ (1 SD).

Correlation between Roche monoclonal EIA and Abbott polyclonal EIA

Graphs comparing the CEA serum concentrations obtained with the two methods are shown in figure 1. The corresponding data from linear regression analysis are given in table 5 .

Tab. 5. Correlation between monoclonal EIA from Roche (y) and polyclonal EIA from Abbott (x).

\begin{tabular}{lllll}
\hline $\begin{array}{l}\text { Concen- } \\
\text { tration } \\
\text { range } \mu \mathrm{g} / \mathrm{l}\end{array}$ & $\begin{array}{l}\text { Number } \\
\text { of } \\
\text { samples }\end{array}$ & $\begin{array}{l}\text { Correlation } \\
\text { coefficient } \\
(\mathrm{p}<0.05)\end{array}$ & $\begin{array}{l}\text { Parameters from } \\
\text { linear regression } \\
\text { analysis }\end{array}$ \\
\hline $0-20$ & 294 & $\mathrm{r}=0.948$ & $\mathrm{y}=0.999$ & $\mathrm{x}-0.003$ \\
$0-200$ & 318 & $\mathrm{r}=0.965$ & $\mathrm{y}=1.05$ & $\mathrm{x}+0.146$ \\
\hline
\end{tabular}



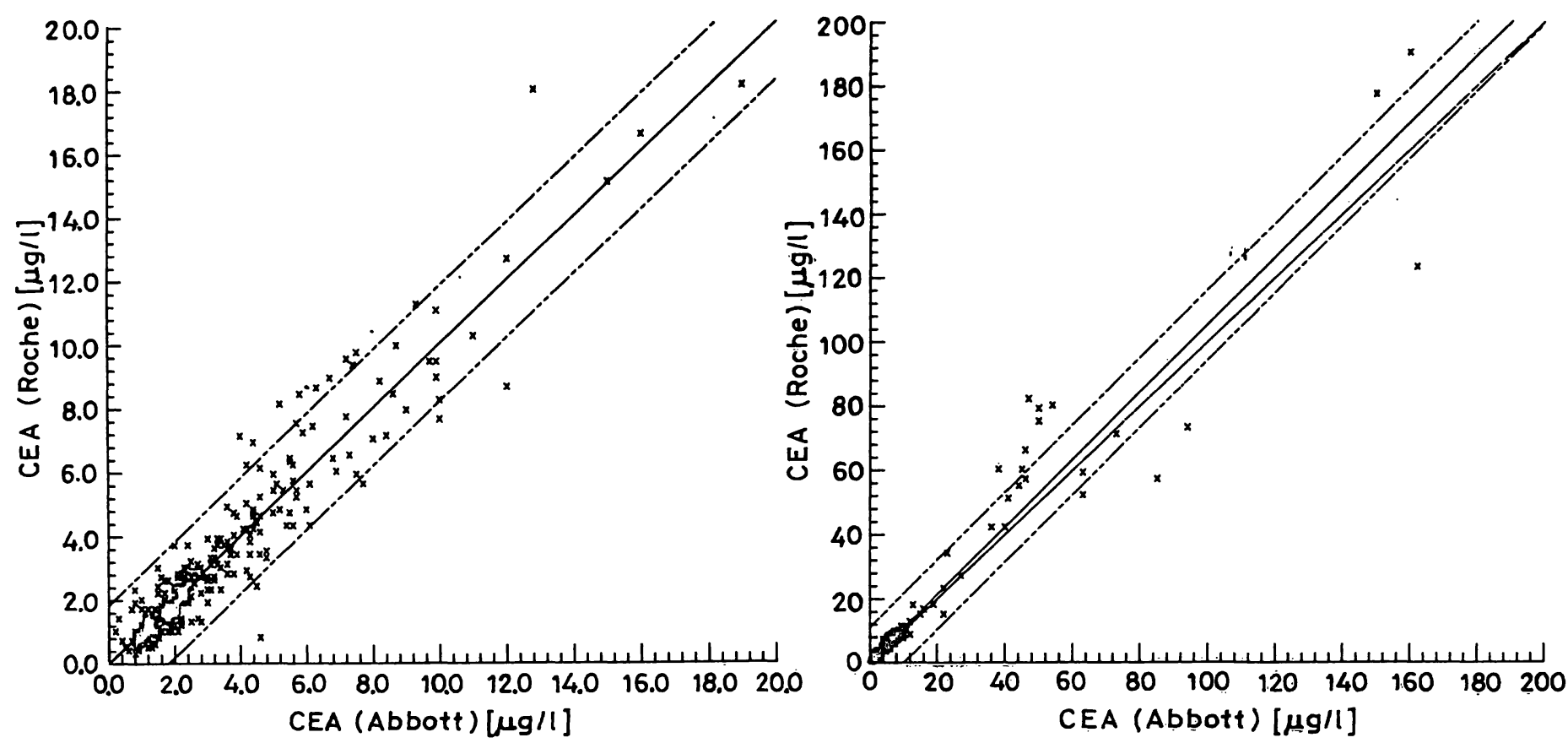

Fig. 1. Comparison of CEA concentrations in human sera found with the polyclonal enzyme immunoassay from Abbott and the monoclonal enzyme immunoassay from Roche. The pictures have been taken directly from computer plots. On the left the data in the range $0-20 \mu \mathrm{g} / \mathrm{l}$ are shown, on the right the data in the range $0-200 \mu \mathrm{g} / \mathrm{l}$.

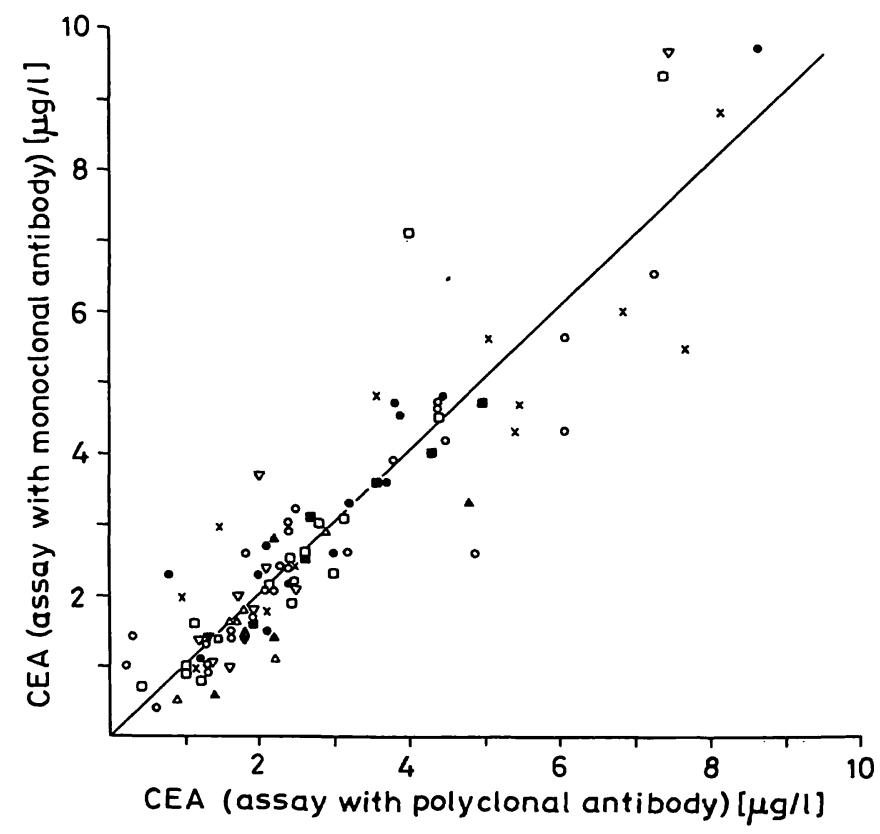

Fig. 2. Comparison of CEA concentrations from patients with known types of carcinoma. No systematic differences between the two assays can be discerned. See text for further explanation.

Type of carcinoma:

- small cell lung c.

- squamous $c$. lung

a rectum $\mathrm{c}$.

- colon c.

$\Delta$ sigmoïdal colon $c$.

$\Delta$ stomach $\mathrm{c}$.

$\nabla$ mamma c.

$$
\begin{aligned}
& n=6 \\
& n=13 \\
& n=17 \\
& n=27 \\
& n=5 \\
& n=6 \\
& n=9
\end{aligned}
$$

Other diagnosis:

$x$ diverticulitis

$\nabla$ ulcus ventriculi

$$
\begin{aligned}
& \mathrm{n}=12 \\
& \mathrm{n}=2
\end{aligned}
$$

It can be seen that the line of best fit passes through the origin and, for practical purposes, does not differ from the line described by the relationship $y=x$.

Six sets of patient data were not included in figure 1 because of very high values for CEA. These were

Tab. 6. Comparison of CEA levels above $10 \mu \mathrm{g} / 1$ in patients with known tumours.

\begin{tabular}{lrrr}
\hline \multirow{2}{*}{$\begin{array}{l}\text { Type of } \\
\text { primary carcinoma }\end{array}$} & pat. & \multicolumn{2}{c}{ CEA concentration $(\mu \mathrm{g} / \mathrm{l})$} \\
\cline { 2 - 4 } & & Abbott & Roche \\
\hline Colon & 1 & 500 & 460 \\
& 2 & 54 & 80 \\
Rectum & 3 & 19 & 18 \\
& 4 & 40 & 42 \\
& 4 & 73 & 71 \\
& 5 & 50 & 80 \\
& 6 & 16 & 16.5 \\
Sigmoidal colon & 7 & 11 & 11.5 \\
Stomach & 8 & 1500 & 2150 \\
& 9 & 63 & 52 \\
Pancreas & 10 & 27 & 27 \\
& 11 & 45 & 60 \\
Breast & 11 & 41 & 51 \\
Lung epidermoid & 11 & 46 & 57 \\
Lung small cell & 16 & 150 & 177 \\
Cervix uteri & 17 & 47 & 82 \\
\hline & 18 & 38 & 60 \\
& 13 & 162 & 23 \\
\hline
\end{tabular}




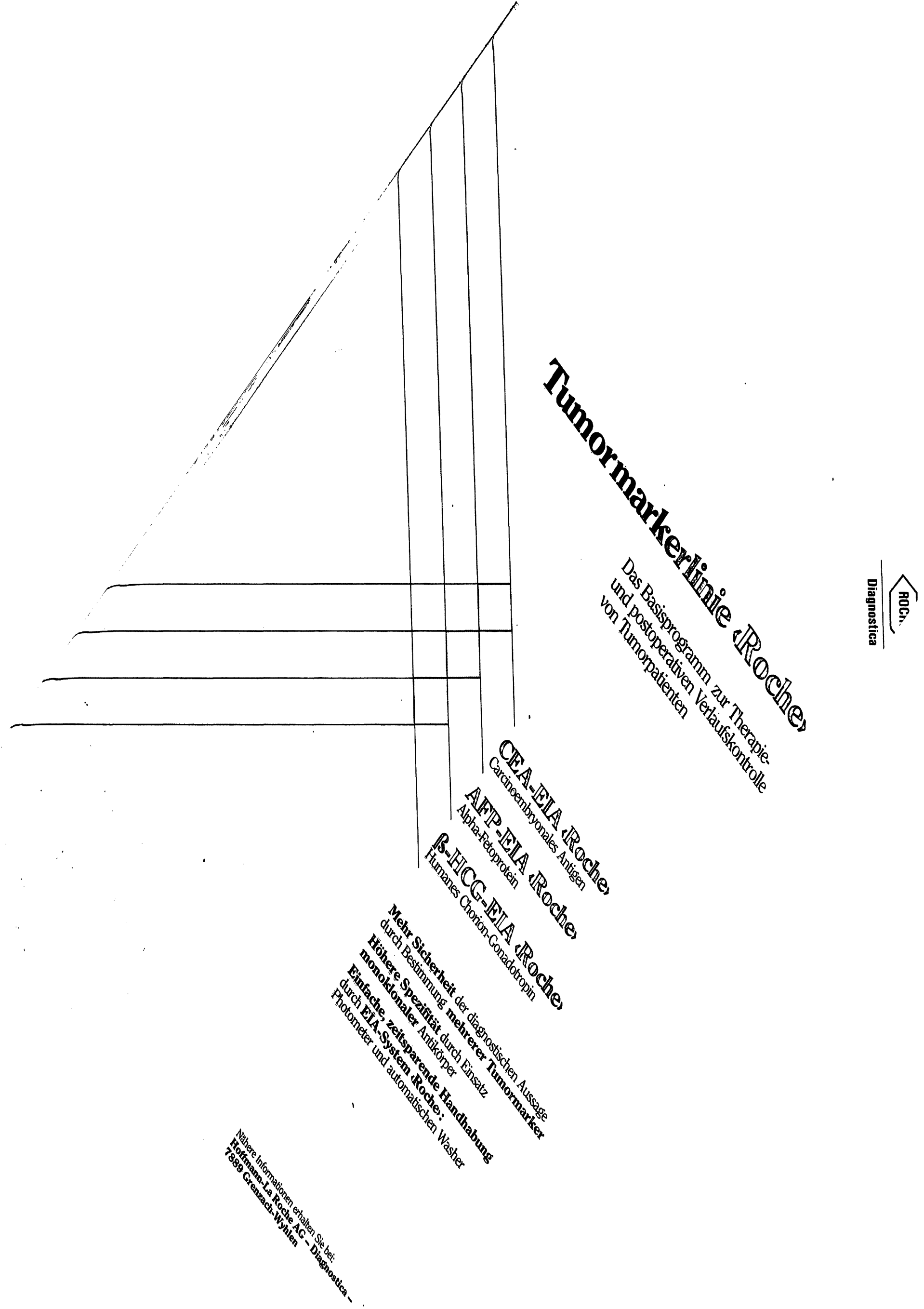


Lectans

\section{Biology, Biochemistry, Clinical Biochemistry · Vol. 5}

Proceedings of IUB Symposium No. 144

The Seventh International Lectin Meeting, Bruxelles, Belgium, August 18-23, 1985

Editors T.C. Bøg-Hansen - E. van Driessche

1986. $17 \mathrm{~cm} \times 24 \mathrm{~cm}$. XVI, 714 pages. With numerous illustrations.

Hardcover. DM 345,-; approx. US \$156.80 ISBN 311010699X

\section{Lectins}

\section{Biology, Biochennistry, Clinical Biochemistry $\cdot$ Vol. 4}

Proceedings of the Sixth International Lectin Meeting. Poznan, Poland, September 2-6, 1984

Editors T. C. Bøg-Hansen - J. Breborowicz

$1985.17 \mathrm{~cm} \times 24 \mathrm{~cm}$. XV, 680 pages. With numerous illustrations.

Hardcover. DM 290,-; approx. US \$131.80 ISBN 3110102986

\section{Lecturins}

\section{Biology, Biochemistry, Climical Biochemistry · Vol. 3}

Proceedings of the Fifth Lectin Meeting, Bern, May 31-June 5, 1982

Editors T. C. Bøg-Hansen - G. A. Spengler

1983. $17 \mathrm{~cm} \times 24 \mathrm{~cm}$. XVI, 708 pages. Numerous illustrations.

Hardcover. DM 245,-; approx. US \$111.40 ISBN 3110095041

\section{Lecturins}

\section{Biology, Biochemistry, Clinical Bíochemistry $\cdot$ Vol. 2}

Proceedings of the Fourth Lectin Meeting, Copenhagen, June 8-12, 1981

Editor T. C. Bøg-Hansen

1982. $17 \mathrm{~cm} \times 24 \mathrm{~cm}$. XVI, 801 pages. Numerous figures and tables.

Hardcover. DM 248,-; approx. US \$112.70 ISBN 3110086808

\section{Lecintins}

\section{Biology, Biochemistry, Clinical Biochemistry · Vol. 1}

Proceedings of the Third Lectin Meeting, Copenhagen, June 1980

Editor T. C. Bøg-Hansen

1981. $17 \mathrm{~cm} \times 24 \mathrm{~cm}$. XII, 418. pages with figures and tables.

Hardcover. DM 120,-; approx. US \$54.50 ISBN 311008483X

\section{$\underset{D E}{W}$ Walter de Gruyter - Berlin - New' York}


1230 and 720,4000 and 6500,1500 and 2150,455 and 580,1150 and 1900 and 500 and $460 \mu \mathrm{g} / \mathrm{l}$, according to the Abbott and Roche assays, respectively.

A subdivision into known types of carcinomas is presented in figure 2. The CEA levels above $10 \mu \mathrm{g} / \mathrm{l}$ are given separately in table 6 .

Visual inspection of the data shows no systematic overall difference between the polyclonal and monoclonal assay for any type of tumour. The differences between the two assays in the individual patient were consistent with time. Thus the Roche method yielded either lower, the same or higher values, compared with the Abbott method (fig. 3).

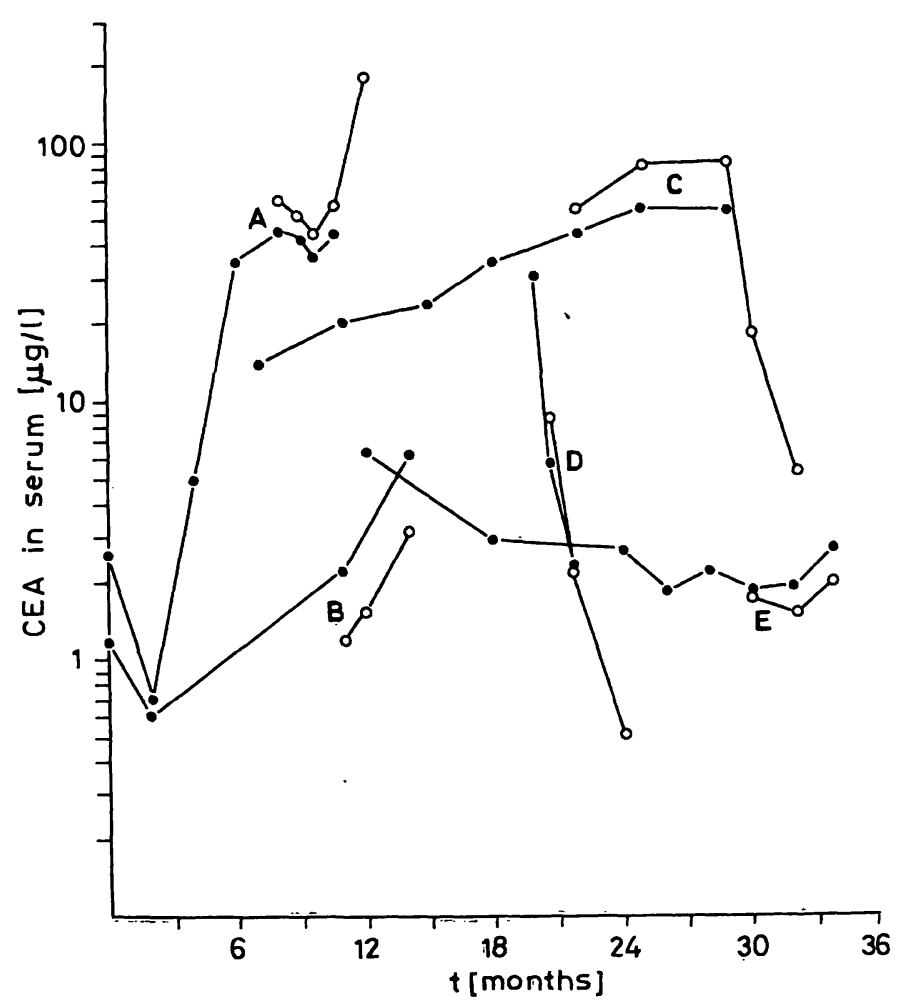

Fig. 3. Typical plots of CEA concentrations in various cases of pathology followed against time. The differences between the two methods can be seen to be consistent within individual patiénts.

0 - Abbott assay

$0-0$ Roche assay

Case A: patient with adenocarcinoma of stomach. At first subtotal stomach resection was applied for, followed by chemotherapy. At the end, progressive disease with metastases to liver and lymph nodes is present.

Case B: patient with adenocarcinoma of stomach. Status after partial resection and adjuvant chemotherapy. Progressive disease.

Case C: patient with adenocarcinoma of coecum, for which a hemicolectomy was performed in the past. Guided by rising CEA level, a right liver lobe metastase was found. The CEA level fell after metastasectomy.

Case D: patient with epidermoid cell carcinoma of cervix and endometrium with lymph metastases. Treatment with cytostatic agents and radiation therapy.

Case E: patient with adenocarcinoma of right lung. Status after lobectomy.

\section{Discussion}

A coefficient of variation of $5 \%$ was found with the Roche assay. This between-day reproducibility compares favourably with previously published data on CEA assays. CVs of $5-15 \%$ have been reported $(4,5,7)$.

This good precision may be explained in part by the high actual absorbance values obtained during the spectrophotometric measurement. An absorbance of about 1.5 was obtained at a CEA concentration of $20 \mu \mathrm{g} / \mathrm{l}$, compared with about 0.6 in the Abbott assay.

A small but consistent difference was observed between CEA serum values obtained with different diluting fluids. After dilution with human serum, the apparent recovery was about $10 \%$ lower than after dilution with acetate buffer, $\mathrm{pH} 5$, from the Roche kit.

This matrix effect may be due to the composition of normal serum or to protein concentration alone. With respect to the latter factor, Kim et al. reported decreasing CEA values when the concentration of bovine serum albumin in their extraction solution was increased to $5 \mathrm{~g} / \mathrm{l}(8)$.

Theoretically this has implications in cases of rising CEA levels during the course of the disease. Suppose a patient's CEA level changes from a level below 20 $\mu \mathrm{g} / \mathrm{l}$ to above this threshold value. The sample is assayed without a diluent below $20 \mu \mathrm{g} / \mathrm{l}$ and is diluted with buffer above this level.

Therefore a discontinuous increase upon the actual increment would occur. However in the opinion of the authors this seems to be no serious disadvantage of the Roche method for routine purposes. Firstly the difference between buffer and serum as diluting fluids is relatively small, compared with the large increases of CEA concentration actually occurring in progressive disease states, see e.g. figure 3.

Secondly, the number of patients concerned is relatively small compared with the large group below 20 $\mu \mathrm{g} / \mathrm{l}$, e. g. see figure 1 . Nevertheless more experiments would be necessary to settle this point in detail.

The 45 degree slope of the regression line (fig. 1) implies that there is no systematic bias between the results obtained with the two methods in patient sera. Therefore we decided to keep the same reference interval ( $95 \%$ confidence limit) for the Roche assay as in use for the Abbott assay, i. e. up to $4.5 \mu \mathrm{g} / \mathrm{l}$ (5).

One of the arguments for changing from an assay using a polyclonal antibody to one with a monoclonal antibody could be the expectation of greater speci- 
ficity and/or sensitivity for particular types of tumours.

Rogers et al. (9) described a monoclonal antibody with a preference for CEA in the serum of stomach carcinoma patients. Staab reported that the present Roche assay was more specific for CEA isomers from patients with colon carcinoma than the Roche radioimmunoassay with polyclonal antiserum (6).

However Buchegger et al. (10) and Oehr et al. (11) did not observe particular organ specificity with monoclonal anti-CEA antobodies. In our study no clusters of the data from any classified type of carcinoma were evident (fig. 2, tab. 6).

The only exception was pancreas carcinoma, all our three patients with advanced metastatic disease giving higher CEA levels with the Roche assay. However, in view of the limited number of subjects this aspect needs further study.

The good general correspondence would imply that the assay using monoclonal antibody is no more organ specific than the one using polyclonal antibody.

According to the manufacturer the new double monoclonal Abbott assay correlates favourably with the

\section{References}

1. Ravry, M., Moertel, C. G., Schutt, A. J. \& Go, V. L. W. (1974) Cancer 34, 1230-1234.

2. Go, V. L. W. \& Zamchek, N. (1982) Cancer 50, 26182623.

3. Begent, R. H. J. (1984) Ann. Clin. Biochem. 21, 231-238.

4. Maiolini, R., Bagrel, A., Chavance, C., Krebs, B., Herbeth, B. \& Masseyeff, R. (1980) Clin. Chem. 26, 1718-1722.

5. Fleisher, M., Nisselbaum, J. S., Loftin, L., Smith, C. \& Schwartz, M. K. (1984) Clin. Chem. 30, 200-205.

6. Staab, H. J., Glock, S. \& Hornung A. (1982) Tumor Diagnostik \& Therapie 3, 183-194. polyclonal version tested here. Thus, the Roche and Abbott assays currently available should give equivalent overall results.

In individual cases relatively large differences between the two methods can be obtained (fig. 3). For instance case $B$ from figure 3 demonstrates that a change of method from Abbott to Roche at 12 months would have falsely led to the conclusion that CEA production had decreased, whereas it is clear that the opposite is true.

This implies that in order to change from one method to another a transition period is necessary in every patient, in order to establish a new baseline. After an appropriate transition period, the monoclonal EIA of Roche has been used without problems as the routine method for CEA determinations in both authors' laboratories since the summer of 1984.

\section{Acknowledgement}

Thanks are due to members of the Medical Staff of the Juliana Hospital for their kind cooperation, to Mr. B. Leerkes for technical assistance and to Mrs. G. Stalknecht for typing the manuscript.
7. Kubasik, N. P. \& Sine, H. E. (1983) Clin. Chem. 29, 2004. 8. Kim, Y. D., Tomita, J. T., Schenck, J. R., Moeller, C., Weber, G. F. \& Hirata, A. A. (1979) Clin. Chem. 25, $773-$ 776.

9. Rogers, G. T., Rawlings, G. A., Keep, P. A., Cooper, E. W. \& Bagshawe, K. D. (1981) Br. J. Cancer 44, 371-380.

10. Buchegger, F., Phan, M., Rivier, D., Carrel, S., Acolla, R. S. \& Mach, J. P. (1982) J. Immunol. Meth. 49, 129-139.

11. Oehr, P., Adolphs, H., Wustrow, A. \& Derigs, G. (1981) Tumor Diagnostik \& Therapie 2, 189-194.

Dr. H. L. J. M. Fleuren Klin.-Chem.-Laboratorium Dokter J. H. Jansenziekenhuis Postbus 5000 NL-8300 GA Emmeloord 